\title{
Isotope-dilution and its effects on measurements of nitrogen and phosphorus uptake by oceanic microplankton
}

\author{
W. G. Harrison \& L. R. Harris \\ Marine Ecology Laboratory, Bedford Institute of Oceanography, Dept. of Fisheries and Oceans, P. O. Box 1006, Dartmouth, \\ Nova Scotia B2Y 4A2, Canada
}

\begin{abstract}
Nitrogen $\left(\mathrm{NH}_{4}{ }^{+}\right)$and phosphorus $\left(\mathrm{PO}_{4}{ }^{3-}\right)$ uptake and recycling were measured in timeseries experiments in waters off the coast of Hawaii and in the Sargasso Sea. Patterns of uptake and recycling were similar but regionally distinct. In Hawaii, uptake rates were initially rapid but essentially ceased after only a few hours in inshore experiments; recycling rates continued for $24 \mathrm{~h}$ Offshore, recycling rates were variable but decreased significantly with incubation time; uptake, on the other hand, continued for $24 \mathrm{~h}$ and paralleled photosynthetic carbon uptake. Uptake and recycling fluxes balanced after $24 \mathrm{~h}$. In the Sargasso Sea, both soluble reactive phosphorus (SRP) uptake and recycling rates decreased with incubation time but were also in balance. Isotope-dilution, resulting from the in vitro production (recycling) of unlabelled substrate was significant and if ignored, could account for 1.5 to 3 -fold underestimates in computed uptake rates.
\end{abstract}

\section{INTRODUCTION}

Radioactive and stable isotope tracer techniques have been used extensively in the study of growth and metabolism of marine microplankton (Harrison 1983b). Our present understanding of plankton production processes derives largely from the application of these techniques. However, since their introduction, there has been little consensus on the correct interpretation of tracer data, particularly with regard to complex, natural community studies (e.g. Eppley 1980, Peterson 1980). Much of the recent concern has centered on the extent of cycling and exchange of the traced compound among the various functional components of plankton communities including isotope losses due to excretion and respiration (e.g. Smith 1982, Smith \& Platt 1984, Smith et al. 1984).

Although most research has focused on pathways of carbon flow, other elements important in the metabolism and structure of plankton (e.g., N, P, Si) have been studied using appropriate tracers; interpretations of these experiments have suffered similarly due to the complex nature of isotopic movements during incubation (e.g. Rigler 1973). In the past, tracer studies of nitrogen and phosphorus in marine waters, for exam- ple, have employed simplified equations based on the assumption that (re-)cycling of the traced compound is negligible during incubation; models of nutrient uptake have generally been based on observations of tracer movements through only one system compartment, i.e. the particulate matter (Nalewajko \& Lean 1980, Harrison 1983b). Studies based on observations of isotope movements between dissolved and particulate components, however, have shown that substantial recycling of nitrogen and phosphorus does occur during incubations (e.g. Harrison 1978, Caperon et al. 1979, Glibert 1982, Paasche \& Kristiansen 1982, Harrison 1983a). These studies have pointed to the obvious inadequacies inherent in the assumptions and tracer models used to date (Harrison 1983b) and have further shown that serious and systematic errors in computed nutrient flux rates occur as a consequence (Glibert et al. 1982). While there is evidence that 'bottle artifacts' such as substrate depletion may be important in explaining non-linear nutrient uptake kinetics in natural microplankton populations (Goldman et al. 1981b), isotope-dilution, resulting from the production (recycling) of the traced substance in vitro, may be a more generally applicable cause (Glibert et al. 1982, Harrison 1983c, Garside 1984, Garside \& Glibert 1984). This 
had led to speculation about the widespread significance of these new findings and how they affect current estimates of plankton production based on nutrient fluxes (e.g. Harrison 1983b). It is not unreasonable to assume, for example, that isotope-dilution and recycling errors may be more important in the oligotrophic oceans where substrate concentrations are lower and regenerative fluxes are of proportionally greater importance than in coastal waters (see Harrison 1983b).

Experiments carried out off the coast of Hawaii, as part of the project PRPOOS (Plankton Rate Processes in the Oligotrophic Oceans), and in the Sargasso Sea provided an opportunity to look in more detail at the uptake and recycling of nitrogen $\left(\mathrm{NH}_{4}{ }^{+}\right)$and phosphorus $\left(\mathrm{PO}_{4}{ }^{3-}\right)$ in both coastal and oceanic waters and more specifically to evaluate the effects of isotopedilution on nitrogen and phosphorus uptake rates. Results confirm earlier conclusions that 'conventional' productivity calculations significantly underestimate true nutrient uptake rates as a result of in vitro nutrient recycling and suggest that the effects (errors) are largely independent of region.

\section{METHODS}

Four time-series experiments were carried out in Hawailan waters during the period 26 August to 15 September 1982. Samples in the first 2 experiments (KB1, KB2) were collected in a eutrophic embayment, Kaneohe Bay, and samples for the latter 2 (OS1, OS2) were collected in oceanic waters, approximately $6 \mathrm{~km}$ to the south and southwest of the island of Oahu. Inshore samples were taken from surface waters with a polyethylene bucket; offshore samples were collected from $30 \mathrm{~m}$ using Go-Flo Niskin bottles. Clean techniques were used throughout as recommended by Fitzwater et al. (1982) to prevent metal contamination. Two time-series experiments were done in the Sargasso Sea $\left(35^{\circ} 20^{\prime} \mathrm{N}, 62^{\circ} 30^{\prime} \mathrm{W}\right)$ during April 1983. Samples were collected from $10 \mathrm{~m}$ using $30 \mathrm{l}$ Niskin bottles; clean techniques were not used in these experiments.

Incubations in the Hawaii experiments were carried out in $4 \mathrm{I}$ polycarbonate bottles especially cleaned as above. Samples were collected before dawn and incubations began between 0700 and 0900 h except for one experiment (OS1) which began at $1100 \mathrm{~h}$, local time. Sargasso Sea samples were collected at $0800 \mathrm{~h}$ and incubations began within 1 to $2 \mathrm{~h}$. Samples were inoculated with either $\left({ }^{15} \mathrm{NH}_{4}\right)_{2} \mathrm{SO}_{4}$ (99 atom \% enriched) to a final concentration of $0.05 \mu \mathrm{M}$ or carrierfree ${ }^{33} \mathrm{PO}_{4}{ }^{3-}$ as phosphoric acid (1 to $1.5 \mu \mathrm{Ci} \mathrm{l}^{-1}$ ) and incubated under natural sunlight in deck incubators attenuated (nickel screening) to $40 \%$ incident light
(Hawaii) and 50\% incident light (Sargasso). Surface seawater was used to control temperature. Nitrogen measurements were not made during the second inshore Hawaii experiment (KB2) nor during either of the Sargasso Sea experiments.

Replicate subsamples for analysis of substrate $\left(\mathrm{NH}_{4}{ }^{+}, \mathrm{PO}_{4}{ }^{3-}\right)$ concentration and isotope content were collected at 'time zero' and approximately every $3 \mathrm{~h}$ thereafter for 24 to $30 \mathrm{~h}$. Where multiple incubation bottles were required, i.e. nitrogen experiments, the bottles from which subsamples were taken differed at each sampling time. Particulate chemical analyses were done less frequently but showed little change during incubations (Renger 1983); particulates were measured only at 'time zero' in the Sargasso Sea experiments. Only initial values, therefore, were used in subsequent computations. Ammonium concentrations were determined using the method of Solorzano (1969), and $\mathrm{PO}_{4}{ }^{3-}$ by a slight modification of the alcohol extraction method described by Strickland \& Parsons (1972), corrected for arsenate interference (Johnson 1971). Particulate organic nitrogen (PON) and phosphorus (POP) were determined using the methods of Sharp (1974) and Solorzano \& Sharp (1980), respectively.

Details of sample preparation and isotope analysis are given elsewhere (Harrison 1983a, Laws et al. 1984). Briefly, $\mathrm{NH}_{4}{ }^{+}$was recovered from the seawater samples by distillation and conversion to $\mathrm{N}_{2}$, as were particulate samples, using a micro-Dumas conversion method similar to that given by Kristiansen \& Paasche (1982). ${ }^{15} \mathrm{~N}$ was analyzed by emission spectrometry (Fiedler \& Proksch 1975). ${ }^{33} \mathrm{P}$ samples were separated into 2 fractions, particulates and soluble reactive phosphorus (SRP) (alcohol soluble, molybdate- $\mathrm{PO}_{4}{ }^{3-} \mathrm{Com}$ plex; Strickland \& Parsons 1972) for analysis of radioactivity by scintillation spectrometry. All analyses were done on fresh (unfrozen) samples kept refrigerated in the dark and analyzed within $1 \mathrm{~d}$ of collection.

Nutrient uptake and recycling rates were computed using a modification (Laws 1984) of the equations of Blackburn (1979), Caperon et. al. (1979) and Glibert et al. (1982). Nutrient regeneration rates ( $r$ ) were computed from

$$
r=\frac{\ln \left(R_{t} / R_{0}\right)}{\ln \left(S_{t} / S_{0}\right)} \quad\left(S_{0}-S_{t}\right) / t
$$

where $R_{0}, R_{t}$ and $S_{0}, S_{t}=$ substrate specific activities and concentrations at times zero and $t$, respectively

The conventional equation for the calculation of nutrient uptake (Dugdale \& Goering 1967) is based on the assumption that substrate specific activity remains constant during the course of the incubation and is given by 


$$
\mathrm{e}=\left(\mathrm{R}_{\mathrm{t}}^{\prime} \cdot \mathrm{PM}\right) /\left(\mathrm{R}_{\mathrm{o}} \cdot \mathrm{t}\right)
$$

where $\mathrm{R}_{\mathrm{t}}{ }^{=}$specific activity of the particulate matter at time $\mathrm{t}$ (corrected for any time-zero activity); $\mathrm{PM}=$ particulate matter concentration (in nutrient units, i.e. $\mathrm{N}$ or $\mathrm{P}$ in this case).

Nutrient uptake corrected for changes in substrate specific activity, i.e. 'isotope-dilution' (Glibert et al. 1982 ) is given by the equation

$$
P=\left(R_{1}^{\prime} \cdot P M\right) /(\bar{R} \cdot t)
$$

where $\bar{R}=$ average substrate specific activity over the course of the incubation (Laws 1984) and computed from

$$
\overline{\mathrm{R}}=\left(\mathrm{R}_{\mathrm{o}} \cdot \mathrm{S}_{\mathrm{o}}-\mathrm{R}_{\mathrm{t}} \cdot \mathrm{S}_{\mathrm{t}}\right) /(\mathrm{u} \cdot \mathrm{t})
$$

and $u$ (by mass balance, Eq. 1$)=r-\left(S_{t}-S_{0}\right) / t$.

The ratio $\mathrm{P} / \mathrm{Q}$ can be used as an index of the effects of isotope-dilution on uptake calculations (see also Glibert et al. 1982, Harrison 1983b). A detailed discussion of the adequacy of these equations and the compartmental models they represent are discussed elsewhere (Smith et al. 1985).

\section{RESULTS}

Fig. 1 and 2 show changes in the distributions of isotopes and substrate concentrations during two of the Hawaii time-series experiments. Only one example for each of the inshore and offshore experiments is shown; however, distributional patterns were similar in the other experiments.

Initial $\mathrm{NH}_{4}{ }^{+}$concentrations were similar inshore and offshore $\left(0.10\right.$ to $0.20 \mu \mathrm{g}$-at $\left.\mathrm{N}^{-1}\right)$ and, with the exception of OS2, changed little during the course of incubation; nutrient depletion was not evident despite relatively low initial concentrations. Significant changes (decrease) in substrate specific activity, however, were evident in all experiments; isotope-dilution was greatest inshore. Differences in the ${ }^{15} \mathrm{~N}$ labelling patterns of the particulate matter were also seen between inshore and offshore experiments. Inshore, particulates were rapidly labelled (no change in ${ }^{15} \mathrm{~N}$ content was apparent after only $1 \mathrm{~h}$ ) whereas ${ }^{15} \mathrm{~N}$ incorporation offshore continued for $24 \mathrm{~h}$ (the rate of labelling appeared to decrease between 6 and $9 \mathrm{~h}$ offshore, coincident with the onset of darkness)

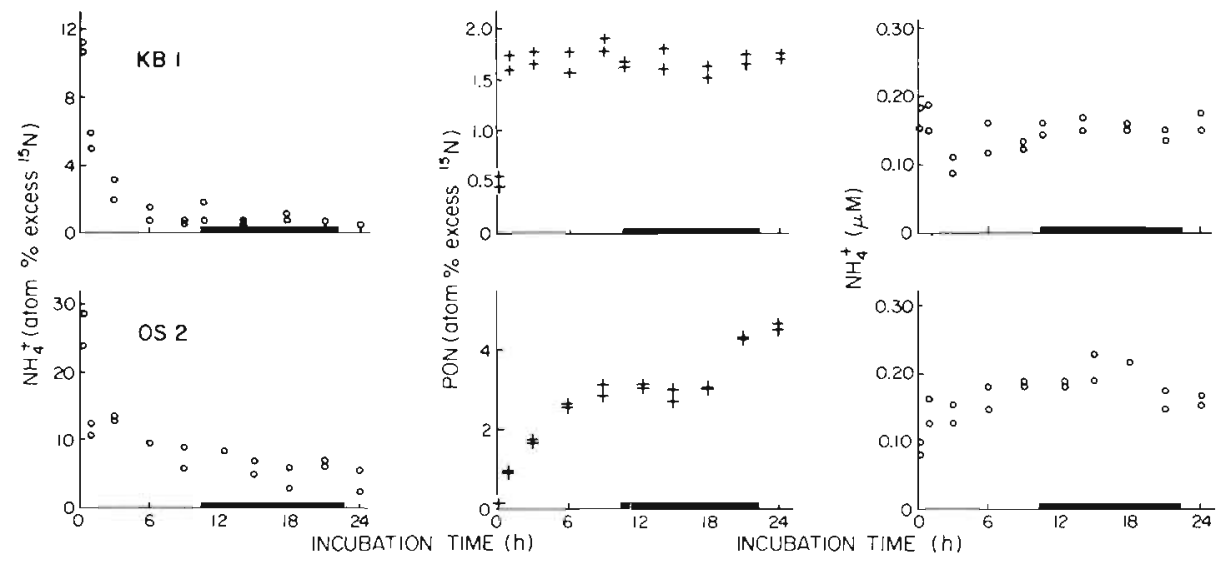

Fig. 1. Distribution of ${ }^{15} \mathrm{~N}$ in $\mathrm{NH}_{4}{ }^{+}$ and particulate organic nitrogen (PON) and changes in $\mathrm{NH}_{4}{ }^{+}$concentrations during time-series experiments in Hawaiian coastal waters. $\mathrm{NH}_{4}{ }^{+}$concentrations include added ${ }^{15} \mathrm{NH}_{4}^{+}$(i.e. $\approx 0.05$ $\mu \mathrm{g}$-at $\mathrm{N} \mathrm{l}^{-1}$ ). Time axis represents hours from start of experiment. $\mathrm{KB} 1=$ Kaneohe Bay, start time $0800 h_{i}$ OS1 = offshore, start time $1100 \mathrm{~h}$

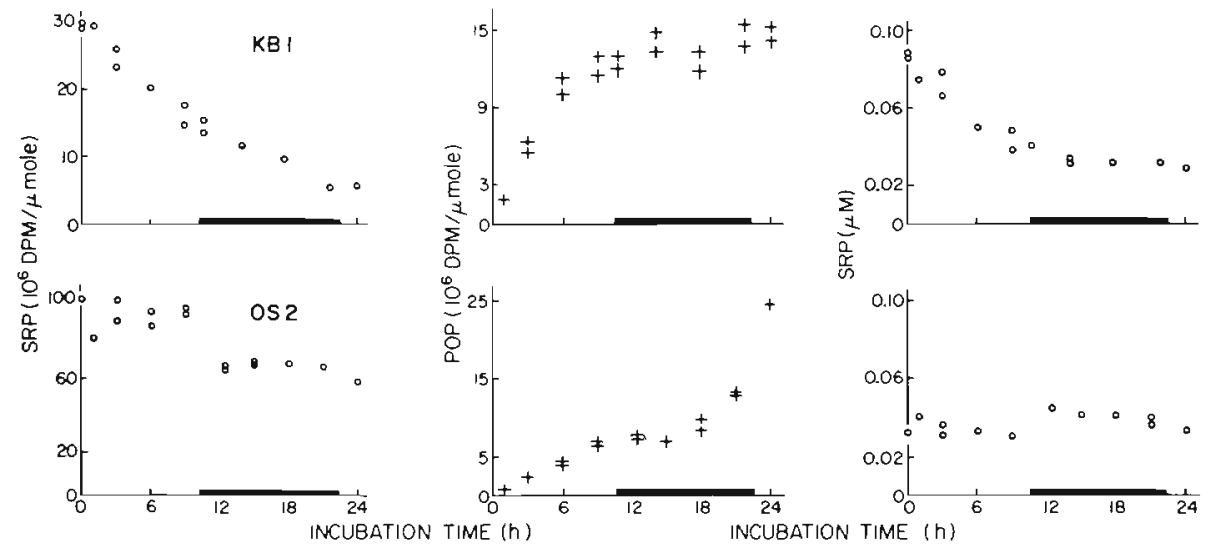

Fig. 2. Distribution of ${ }^{33} \mathrm{P}$ in soluble reactive phosphorus (SRP) and particulate organic phosphorus (POP) and changes in SRP during time-series experiments in Hawaiian coastal waters. Symbols as in Fig. 1 

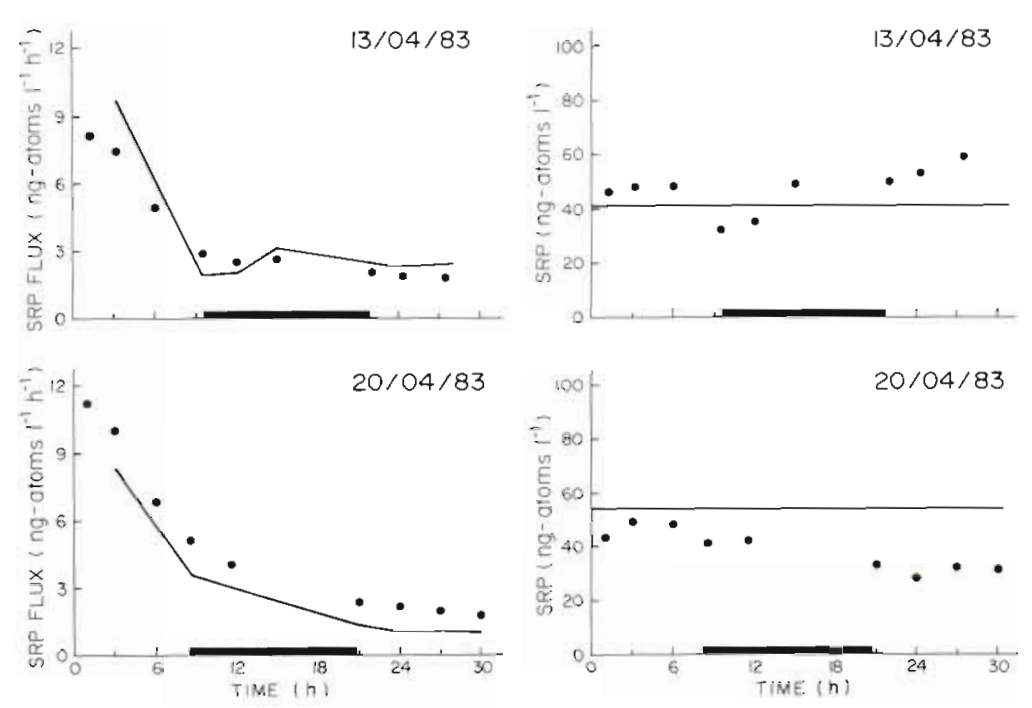

Fig. 3. Left: time-dependence of SRP uptake (filled circles) and recycling (solid line) in Sargasso Sea experiments. Uptake rates (P) corrected for isotope-dilution. Right: changes in SRP concentrations (filled circles); solid line is initial concentration. Time axis represents hours from start of experiment. Start times: 0900 h (13 Apr 1983) and $0930 \mathrm{~h}$ (20 Apr 1983)
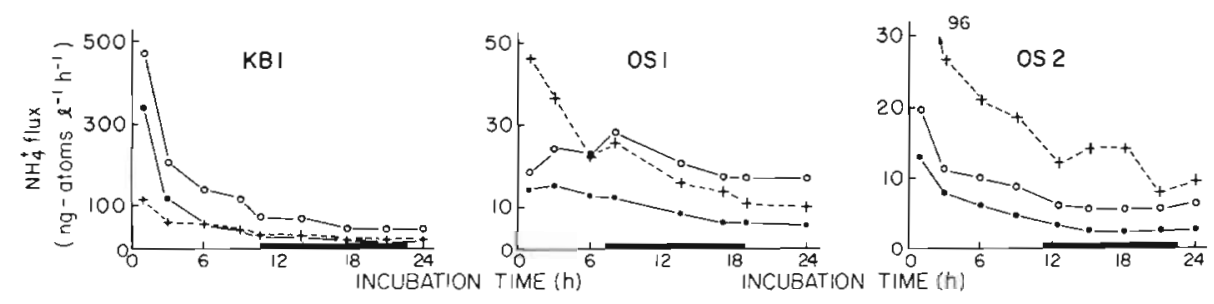

Fig. 4. Time-dependence of $\mathrm{NH}_{4}{ }^{+}$uptake (circles) and recycling (crosses) rates. Closed circles represent conventional (see 'Methods') uptake calculations, open circles are uptake rates corrected for isotope-dilution. Time axis represents hours from start of experiment. $\mathrm{KB} 1=$ Kaneohe Bay, start time $0800 \mathrm{~h} ; \mathrm{OS} 1=$ offshore, start time $1100 \mathrm{~h}, \mathrm{OS} 2=$ offshore, start time $=0700 \mathrm{~h}$

Phosphorus experiments were similar in that the rate of particulate labelling was initially rapid inshore and decreased markedly with time. Offshore, labelling continued for the duration of the incubations and also appeared to slow during the dark period. Isotopedilution of the SRP fraction was much less pronounced, particularly offshore, than in the nitrogen experiments although still significant. In addition, while SRP concentrations were low and relatively invariant offshore, concentrations inshore decreased with time. Inshore SRP concentrations were about 2 -fold higher than offshore concentrations. Particulate biomass was also significantly higher inshore; initial chlorophyll $a$, organic nitrogen and organic phosphorus values averaged $2.05,31.4$, and $5.8 \mu \mathrm{gl}^{-1}$, respectively, as compared to $0.10,5.9$, and $1.1 \mathrm{ug} \mathrm{l}^{-1}$ offshore.

The distributions of ${ }^{33} \mathrm{P}$ in the SRP and particulate fractions in the Sargasso Sea experiments (not shown) were similar to the inshore Hawaii experiments, i.e. particulate labelling was rapid, essentially ceasing after $6 \mathrm{~h}$, and isotope-dilution of the SRP was evident. SRP concentrations, however, were initially very low (0.04 $\mu \mathrm{g}$-at $\mathrm{P}^{-1}$ ) increasing slightly with time in one experiment and decreasing in the other (Fig. 3).
Chlorophyll $a$ and particulate phosphorus concentrations averaged 0.40 and $2.5 \mu \mathrm{g} \mathrm{l}^{-1}$, respectively and were intermediate between the Hawaii inshore and offshore values.

The time-dependence of uptake and recycling rates was evident from inspection of fluxes computed for each sampling time (Fig. 3,4 \& 5). In Hawaii, $\mathrm{NH}_{4}^{+}$ uptake rates inshore decreased by almost an order of

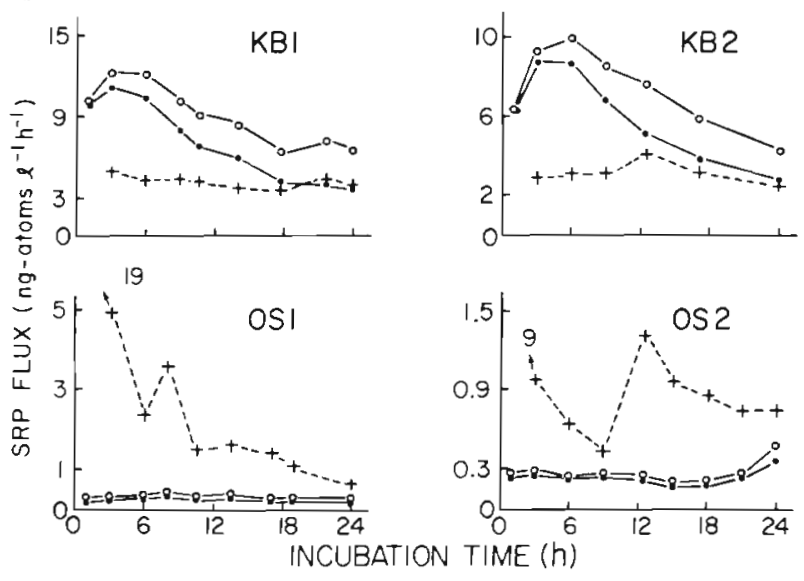

Fig. 5. Time-dependence of SRP uptake and recycling rates. Symbols as in Fig. 4; KB2 = Kaneohe Bay, start time $0700 \mathrm{~h}$ 
Fig. 6. Relation between estimates of $\mathrm{NH}_{4}{ }^{+}$uptake corrected (P) and uncorrected ( $(\varrho)$ for isotope-dilution, and incubation time. Symbols as in Fig. 4
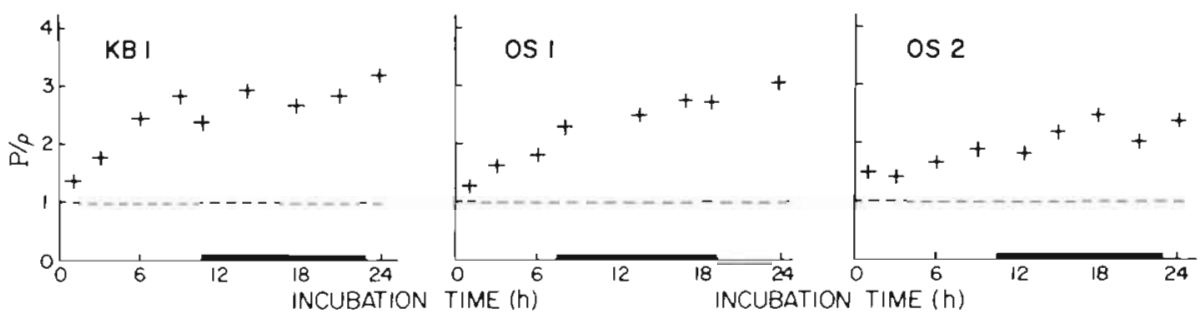

magnitude in $24 \mathrm{~h}$. Recycling rates were less variable but still decreased with time. Uptake rates exceeded recycling rates initially but fluxes converged later. In contrast, recycling rates decreased with time more than did uptake rates offshore and exceeded uptake initially. However, as seen inshore, fluxes tended to converge with time

Phosphorus fluxes showed a similar pattern. Uptake rates dominated inshore but decreased with time. Recycling rates were essentially constant. Offshore, recycling rates, although highly variable, were dominant and decreased markedly with time. Some of the variability appeared to be associated with the onset of darkness, i.e. an apparrent burst in SRP recycling was evident (see also Smith et al. 1985). Uptake rates, on the other hand, were reasonably constant.

Phosphorus uptake and recycling in the Sargasso Sea experiments decreased with time in a similar manner (Fig. 3); fluxes were approximately in balance for all sampling intervals.

In both inshore and offshore Hawaii experiments, isotope-dilution had a significant effect on estimates of $\mathrm{NH}_{4}{ }^{+}$and SRP uptake rate (compare open and filled symbols, Fig. $4 \& 5$ ). Moreover, the effects were apparently time-dependent (Fig. $6 \& 7$ ). Conventional estimates of $\mathrm{NH}_{4}{ }^{+}$uptake (@) inshore, for example, underestimated 'true' uptake by more than a factor of 3 (i.e.

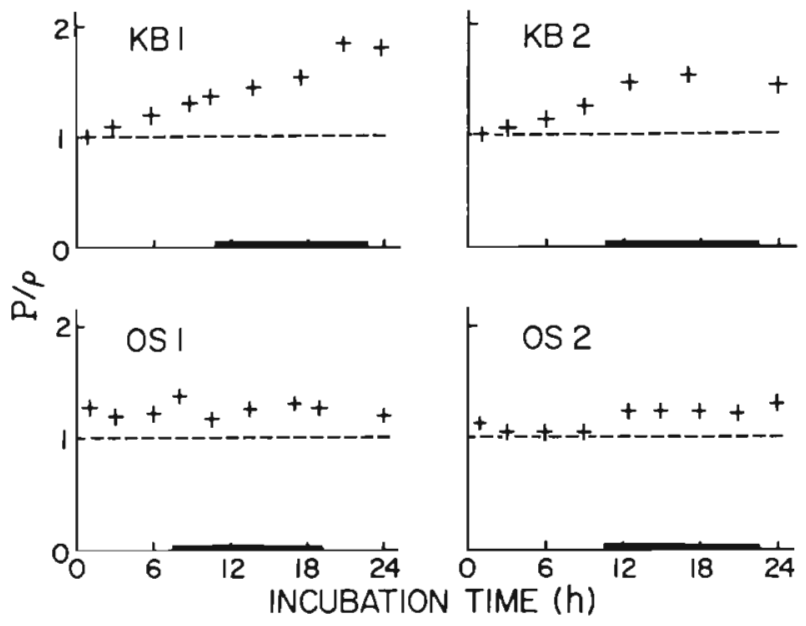

Fig. 7. Relation between estimates of SRP uptake corrected (P) and uncorrected $(\varrho)$ for isotope-dilution, and incubation time Symbols as in Fig. 4
$\mathrm{P} / \mathrm{Q}$ ) after $24 \mathrm{~h}$ incubation. Offshore the effects were slightly less on the average but still resulted in a $\mathrm{P} / \mathrm{\varrho}$ ratio greater than 2 for long incubations. Phosphorus experiments showed a similar time-dependency pattern. However, the absolute magnitude of errors was less. Inshore, $\mathrm{P} / \mathrm{Q}$ ratios were 1.4 to 1.8 for $24 \mathrm{~h}$ incubations while ratios offshore were 1.2 to 1.3 .

Isotope-dilution errors were also important in the Sargasso Sea phosphorus experiments; $\mathrm{P} / \mathrm{g}$ ratios ranged from $1.0(\mathrm{t}=1 \mathrm{~h})$ to $1.8(\mathrm{t}=24 \mathrm{~h})$, i.e. were in the same general range as the inshore Hawaii values.

\section{DISCUSSION}

Our results show, as have others (e.g. Goldman et al. 1981b, Glibert et al. 1982), that conventional methods and assumptions used to compute nutrient uptake rates of natural marine microplankton assemblages are likely in error (see also Harrison 1983b). Not only was substantial substrate recycling evident in both $\mathrm{NH}_{4}{ }^{+}$ and SRP experiments but computed nutrient fluxes (uptake and recycling) were strongly time-dependent (see Glibert \& Goldman 1981, Goldman et al. 1981b, Glibert et al. 1982, Harrison 1983c). Moreover our results showed notable regional differences in patterns of nutrient uptake and recycling.

Considerable insight into the dynamics of nutrient uptake and recycling are provided by the time-series data (see Goldman et al. 1981b). Firstly, nutrient uptake processes dominated in our inshore experiments. This was most apparent in the phosphorus data and resulted in a significant decrease in substrate concentrations over time. In this case, substrate depletion could help explain the observed decrease in uptake rates with time (see also Goldman et al. 1981b, Goldman \& Glibert 1982). On the other hand, substrate depletion was not evident in the nitrogen experiment and could not have accounted for the observed timedependent decrease in uptake rates. It is possible that significant changes in the microplankton populations occurred during incubation (i.e. mass mortality), accounting for the near cessation of uptake within a few hours. However, results from subsequent experiments in Kaneohe Bay (Landry et al. 1984) do not support this theory. In other studies where rapid initial 
$\mathrm{NH}_{4}{ }^{+}$uptake was observed it has been suggested that biochemical feedback inhibition mechanisms may help explain such uptake patterns (Glibert \& Goldman 1981, Goldman \& Glibert 1982).

It is noteworthy that both $\mathrm{NH}_{4}^{+}$and SRP recycling continued at reasonably high rates over the entire $24 \mathrm{~h}$ of incubation. Based on these observations, therefore, it would seem that the optinal sampling strategy in these coastal waters would be to employ relatively short incubations for nutrient uptake measurements. This would appear, however, to be less of a constraint for nutrient recycling measurements, although most reliable estimates are obtained when substrate specific activity is exhibiting greatest change (Garside \& Glibert 1984), i.e. early during incubation based on our findings.

Secondly, $\mathrm{NH}_{4}{ }^{+}$and SRP recycling fluxes appeared to dominate offshore. Rates were highly variable but clearly decreased over time. Recycling rates were particularly high at the first sampling time $(1 \mathrm{~h})$. In contrast, nutrient uptake, although not constant, continued at a high rate for $24 \mathrm{~h}$.

Whether the high initial recycling rates were real, i.e. representative of unperturbed populations, or were a manifestation of bottle confinement is not clear (see also Glibert et al. 1982, Laws 1984). Concurrent measurements were made of microplankton (autotrophic and heterotrophic picoplankton and nanoplankton) populations during both offshore experiments. No mortality was evident in OS1 but significant losses of autotrophic and heterotrophic nanoplankton (flagellates) occurred during the first $12 \mathrm{~h}$ of OS2 (L. Haas unpubl.). Despite the lack of consistent evidence based on mortality, the marked decrease in recycling rates could have been a consequence of some general loss of physiological vigor related to population confinement (e.g. Gieskes et al. 1979). It is interesting to note that the observed increase in SRP uptake (OS2) after $18 \mathrm{~h}$ (Fig. 2 \& 5) coincided with a significant increase in larger ( $>1 \mu \mathrm{m}$ ) heterotropic bacteria (L. Haas unpubl.; see also Ferguson et al. 1984). This, however, was not evident in SRP recycling rates nor in $\mathrm{NH}_{4}{ }^{+}$fluxes. Our results do, nonetheless, point to the possibility that the more oceanic populations exhibited greater sensitivity to bottle confinement, particularly those organisms important in the recycling of $\mathrm{NH}_{4}{ }^{+}$and SRP.

The offshore, nutrient recycling-dominated conditions we observed were consistent with oxygen flux data. Working at the same time and location, Williams et al. (1983) showed that respiration $\left(\mathrm{O}_{2}\right.$ consumption) exceeded production over $24 \mathrm{~h}$ for both experiments, i.e. oxygen changes were negative. Clearly, this situation could not persist for very long periods if 'steadystate' conditions are typical for these oceanic waters (Bienfang \& Szyper 1981, Bienfang et al. 1984). It is likely, therefore, that our sampling was too limited to characterize the dynamic balance in chemical fluxes expected. We have evidence from 2 less intensely sampled phosphorus experiments, for example, that shows uptake exceeding recycling over $24 \mathrm{~h}$ (see also Table 1 in Williams et al. 1983). In the Sargasso Sea also, uptake exceeded recycling in one experiment and recycling was greater in the other. Taken together, fluxes were approximately in balance.

In contrast to the observed patterns of nutrient recycling, uptake rates in both Hawaii offshore experiments continued for $24 \mathrm{~h}$. Although uptake rates were not linear, they followed carbon-14 uptake patterns during the light period (Fig. 8), suggesting that nutrient uptake was not uncoupled from photosynthesis as might be expected (Goldman et al. 1981a, b). Uncoupling, on the other hand, was clearly evident inshore (KB1); $\mathrm{NH}_{4}{ }^{+}$uptake essentially ceased after $\approx 1 \mathrm{~h}$ while ${ }^{14} \mathrm{C}$-uptake continued at a constant rate until the onset of darkness (Renger 1983). It is noteworthy that $\mathrm{NH}_{4}{ }^{+}$uptake rate at the $1 \mathrm{~h}$ sampling at OS2 was
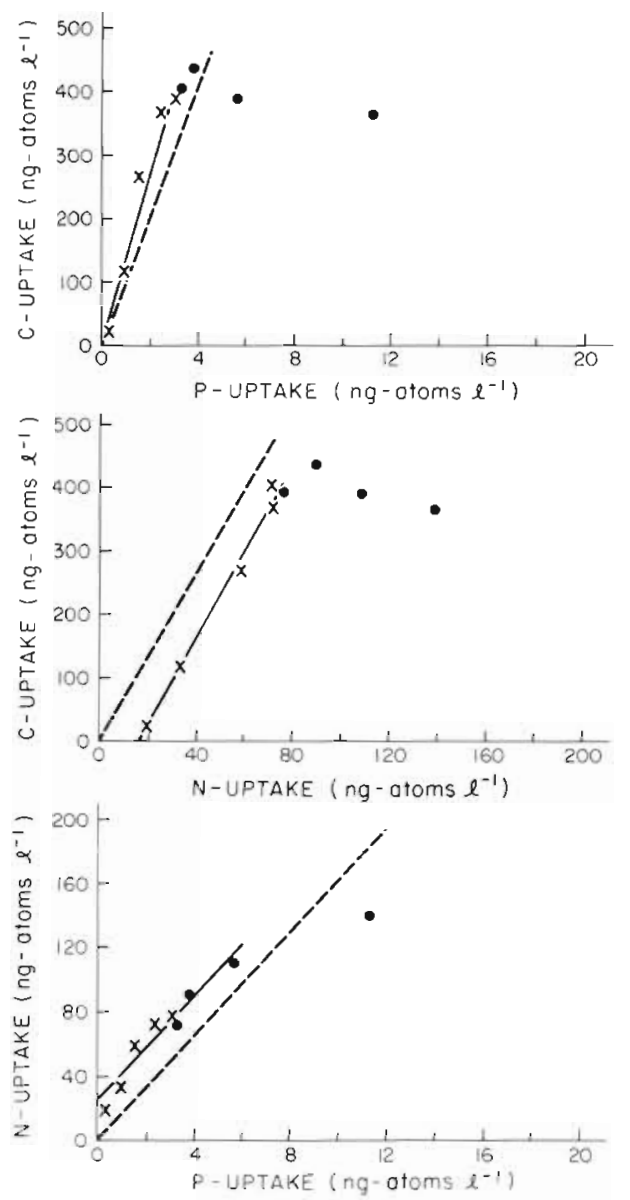

Fig. 8. Photosynthetic carbon and nutrient uptake rates in time-series experiment, OS2. Solid line is least-squares fit of daylight values (crosses); filled circles are dark period values. Dashed line is Redfield ratio, i.e. 106C: 16N:1P by atoms 
elevated relative to that at the other samplings (Fig. 4 \& 8), however, this represented only a small portion of the total mass flux over $24 \mathrm{~h}$ (see Fig. 1); compare this with the approximate $90 \%$ mass flux in KB1 after only $1 \mathrm{~h}$. In our other offshore experiment (OS1), an initial rapid $\mathrm{NH}_{4}{ }^{+}$uptake was not observed (Fig. 4). We have also noted a close correspondence in these experiments between $\mathrm{NH}_{4}{ }^{+}$uptake and estimates of protein synthesis based on ${ }^{14} \mathrm{C}$ end-product labelling (Laws et al. 1985).

Despite the relatively complex patterns of nutrient recycling observed in our bottle incubations, it is evident that for both nitrogen and phosphorus, substrate production, i.e. isotope-dilution, was substantial and as a consequence, had a significant effect on the calculation of nutrient uptake. We found that ignoring the effects of substrate recycling could result in an underestimate of $\mathrm{NH}_{4}{ }^{+}$uptake by as much as 2 to 3 -fold and 1.5 to 2 for phosphorus (SRP) during long ( $24 \mathrm{~h}$ ) incubations. Glibert et al. (1982) were first to bring attention to this computational error and have shown that underestimates of this order can be obtained for $\mathrm{NH}_{4}{ }^{+}$ uptake when incubations are as short as $1 \mathrm{~h}$ (see also Glibert 1982). Our work has shown that isotope-dilu- tion effects are much less important for phosphorus measurements (see also Harrison 1983a). Earlier (Harrison 1983b), we speculated that isotope-dilution errors would be less important in oligotrophic oceans than in coastal waters if microplanktion population levels and growth rates were low (e.g. Sharp et al. 1980). Results from our Hawaii and Sargasso Sea experiments, indeed, provide some evidence that errors are less in the more oligotrophic of the water sampled, particularly with regard to SRP fluxes. Isotope-dilution errors were greatest in the inshore Hawaii experiments, were intermediate in the Sargasso Sea experiments (where biomass levels were relatively high) and were lowest in the offshore Hawaii experiments where biomass was more typically oceanic. This generalization, however, is admittedly based on a very limited data base. Moreover, the observed trend is less convincing when all available data are considered (Table 1); average P/ Q ratios for $\mathrm{NH}_{4}{ }^{+}$ranged from 1.5 to 3.0 in both coastal and oceanic waters and from 1.0 to 1.5 for SRP; regional overlap in values is considerable.

There are in addition to isotope-dilution, other technical problems associated with in vitro nutrient flux measurements, particularly in oligotrophic waters.

Table 1. Summary of 'isotope-dilution' errors (P/Q) for selected ocean regions

\begin{tabular}{|c|c|c|c|c|c|}
\hline Location & No. obs. & $\begin{array}{c}\text { Incubation } \\
\text { time (h) }\end{array}$ & $\overline{\mathrm{x}}$ & (Range) & Source \\
\hline \multicolumn{6}{|l|}{ Nitrogen $\left(\mathbf{N H}_{4}{ }^{+}\right)$} \\
\hline \multicolumn{6}{|l|}{ Oceanic } \\
\hline Sargasso Sea & 123 & $2-4$ & 2.5 & $(1.0-4.4)$ & Glibert (1982), unpubl. \\
\hline Scotia Sea & 14 & 4 & 1.6 & $(1.0-3.5)$ & Glibert (1982), unpubl. \\
\hline \multirow{3}{*}{ Hawaii } & 2 & 1 & 1.4 & $(1.3-1.5)$ & Present study \\
\hline & 2 & 3 & 1.5 & $(1.4-1.6)$ & Present study \\
\hline & 2 & 24 & 2.7 & $(2.4-3.0)$ & Present study \\
\hline \multicolumn{6}{|l|}{ Coastal } \\
\hline Vineyard Sound & 73 & 1 & 2.8 & $(1.0-4.1)$ & Glibert (1982), unpubl. \\
\hline Chesapeake Bay & 38 & 1 & 1.5 & $(1.0-2.0)$ & Glibert (1982), unpubl. \\
\hline \multirow[t]{3}{*}{ Kanoehe Bay } & 1 & 1 & 1.4 & - & Present study \\
\hline & 1 & 3 & 1.8 & - & Present study \\
\hline & 1 & 24 & 3.2 & - & Present study \\
\hline \multicolumn{6}{|l|}{ Phosphorus (SRP) } \\
\hline \multicolumn{6}{|l|}{ Oceanic } \\
\hline E. Tropical Pacific & 7 & 4 & 1.1 & $(1.0-1.1)$ & Harrison (1983a), unpubl. \\
\hline E. Arctic & 5 & 24 & 1.1 & $(1.0-1.2)$ & Harrison (1983a), unpubl. \\
\hline \multirow[t]{3}{*}{ Sargasso Sea } & 2 & 1 & 1.1 & $(1.0-1.2)$ & Present study \\
\hline & 2 & 3 & 1.3 & $(1.3-1.4)$ & Present study \\
\hline & 2 & 24 & 1.5 & $(1.3-1.8)$ & Present study \\
\hline \multirow[t]{3}{*}{ Hawaii } & 2 & 1 & 1.1 & $(1.1-1.2)$ & Present study \\
\hline & 2 & 3 & 1.1 & $(1.1-1.2)$ & Present study \\
\hline & 2 & 24 & 1.2 & $(1.2-1.3)$ & Present study \\
\hline \multicolumn{6}{|l|}{ Coastal } \\
\hline Bedford Basin & 52 & $4-24$ & 1.1 & $(1.0-1.4)$ & Harrison (1983a), unpubl. \\
\hline Peru & 17 & 24 & 1.2 & $(1.0-1.8)$ & Harrison (1983a), unpubl. \\
\hline \multirow[t]{3}{*}{ Kaneohe Bay } & 2 & 1 & 1.0 & $(1.0-1.1)$ & Present study \\
\hline & 2 & 3 & 1.1 & $(1.0-1.1)$ & Present study \\
\hline & 2 & 24 & 1.6 & $(1.4-1.8)$ & Present study \\
\hline
\end{tabular}


Most currently used chemical techniques for example, lack sufficient sensitivity for measuring the extremely low substrate concentrations typical of these waters. For that reason also, it is difficult to add truly 'tracer' concentrations of substrate, especially in ${ }^{15} \mathrm{~N}$ studies (McCarthy 1980, Harrison 1983b). The general similarities we observed in $\mathrm{NH}_{4}{ }^{+}$and SRP uptake and recycling patterns, however, make a reasonably strong case for the use of phosphorus (i.e. ${ }^{33} \mathrm{PO}_{4}{ }^{3-}$ ), which has many analytical advantages over stable isotopes (see Harrison 1983a, b), as a general tracer for studies of the dynamics of inorganic nutrients in oligotrophic oceans.

Acknowledgements. Support for this work was provided with funds from the NSF coordination and logistics grant NSF OCE81-20773 for the PRPOOS program lawarded to $R$. W. Eppley) and from the Marine Ecology Laboratory. We particularly thank R. W. Eppley for giving us the opportunity to participate in this study and E. H. Renger and D. Long for their technical assistance. We also thank L. Haas, J. Marra and P. Glibert for access to their unpublished data. R. Smith, W. Li and P. Glibert provided helpful comments on the manuscript.

\section{LITERATURE CITED}

Bienfang, P. K., Szyper, J. P. (1981). Phytoplankton dynamics in oceanic waters off Kahe Point, Hawaii. Deep Sea Res. 28: $981-1000$

Bienfang, P. K., Szyper, J. P., Okamoto, M. Y., Noda, E. K. (1984). Temporal and spatial variability of phytoplankton in a subtropical ecosystem. Limnol. Oceangr. 29: 527-539

Blackburn, T. H. (1979). Method for measuring rates of $\mathrm{NH}_{4}{ }^{+}$ turnover in anoxic marine sediments, using a ${ }^{15} \mathrm{~N}_{-} \mathrm{NH}_{4}{ }^{+}$ dilution technique. Appl. environ. Microbiol. 37: 760-765

Caperon, J., Schell, D. Hirota, J., Laws, E. (1979). Ammonium excretion rates in Kaneohe Bay, Hawaii, measured by a ${ }^{15} \mathrm{~N}$ isotope dilution technique. Mar. Biol. 54: 33-40

Dugdale, R. C., Goering, J. J. (1967). Uptake of new and regenerated forms of nitrogen in primary productivity Limnol. Oceanogr. 12: 196-206

Eppley, R. W (1980). Estimating phytoplankton growth rates in the central oligotrophic oceans. In: Falkowski, P. G. (ed.) Primary productivity in the sea. Plenum, New York p. 231-242

Ferguson, R. L., Buckley, E. N., Palumbo, A. V (1984) Response of marine bacterioplankton to differential filtration and confinement. Appl, environ. Microbiol 47: 49-55

Fiedler, R., Proksch, G. (1975). The determination of nitrogen15 by emission and mass spectrometry in biochemical analysis: a review. Analytica chim. Acta 78: 1-62

Fitzwater, S.E., Knauer, G. A., Martin, J. H. (1982). Metal contamination and primary production: field and laboratory methods of control. Limnol. Oceanogr 27:544-551

Garside, C. (1984). Apparent ${ }^{15} \mathrm{~N}$ uptake kinetics resulting from remineralization. Limnol. Oceanogr. 29: 204-210

Garside, C. Glibert, P. M. (1984). Computer modelling on ${ }^{15} \mathrm{~N}$ uptake and regeneration experiments. Limnol. Oceanogr 29: $199-204$

Gieskes, W W. C., Kraay, G. W. Baars, M. A. (1979). Current ${ }^{14} \mathrm{C}$ methods for measuring primary production: gross underestimates in oceanic waters. Neth. J. Sea Res. 13: $58-78$

Glibert, P. M. (1982). Regional studies of daily, seasonal and size fraction variability in ammonium remineralization. Mar. Biol. 70: 209-222

Glibert, P. M., Goldman, J. C. (1981). Rapid ammonium uptake by marine phytoplankton. Mar. Biol. Lett. 2: 25-31

Glibert, P. M., Lipschultz, F., McCarthy, J. J., Altabet, M. A. (1982). Isotope dilution models of uptake and remineralization of ammonium by marine plankton. Limnol. Oceanogr. 27: 639-650

Goldman, J. C., Glibert, P. M. (1982). Comparative rapid ammonium uptake by four species of marine phytoplankton. Limnol. Oceanogr. 27: 814-827

Goldman, J. C., Dennett, M. R., Riley, C. B. (1981a). Marine phytoplankton photosynthesis and transient ammonium availability. Mar. Biol. Lett. 2: 323-331

Goldman, J. C., Taylor, C. D., Glibert, P. M. (1981b) Nonlinear time-course uptake of carbon and ammonium by marine phytoplankton. Mar Ecol. Prog. Ser. 6: 137-148

Harrison, W G. (1978). Experimental measurements of nitrogen remineralization in coastal waters. Limnol. Oceanogr 23: $684-694$

Harrison, W. G. (1983a). Uptake and recycling of soluble reactive phosphorus by marine microplankton. Mar. Ecol. Prog. Ser. 10: 127-135

Harrison, W G. (1983b). Use of isotopes. In: Carpenter, E., Capone, D. (ed.) Nitrogen in the marine environment. Academic, New York, p. 763-807

Harrison, W. G. (1983c). The time-course of uptake of inorganic and organic nitrogen compounds by phytoplankton from the Eastern Canadian Arctic: a comparison with temperate and tropical populations. Limnol. Oceanogr 28: 1231-1237

Johnson, D. L. (1971). Simultaneous determination of arsenate and phosphate in natural waters. Environ. Sci. Technol. 5: 411-414

Kristiansen, S., Paasche, E. (1982). Preparation of ${ }^{15} \mathrm{~N}$-labelled phytoplankton samples for optical emission spectrometry. Limnol. Oceanogr. 27: 373-375

Landry, M. R., Haas, L., Fagerness, V L. (1984). Dynamics of microbial communities: experiments in Kaneohe Bay. Mar Ecol. Prog. Ser. 16: 127-133

Laws, E. A. (1984). Isotope dilution models and the mystery of the vanishing ${ }^{15} \mathrm{~N}$. Limnol. Oceanogr. 29: 379-385

Laws, E. A., Harrison, W. G., Ditullio, G. (1985). A comparison of nitrogen assimilation rated based on ${ }^{15} \mathrm{~N}$ uptake and autotrophic protein synthesis. Deep Sea Res. 32: 85-95

Laws, E. A., Redalje, D. G., Haas, L. W., Bienfang, P. K. Eppley, R. W., Harrison, W G., Karl, D. M., Marra, J. (1984). High phytoplankton growth and production rates in oligotrophic Hawaiian coastal waters. Limnol. Oceanogr. 29: 1161-1169

McCarthy, J. J. (1980). Nitrogen and phytoplankton ecology. In: Morris, I. (ed.) Physiological ecology of phytoplankton. Blackwell, Oxford, p. 191-233

Nalewajko, C., Lean, D. R. S. (1980). Phosphorus. In: Morris, I. (ed.) The physiological ecology of phytoplankton. Blackwell, Oxford, p. 235-258

Paasche, E., Kristiansen, S. (1982). Ammonium regeneration by micro-zooplankton in the Oslo Fjord. Mar. Biol. 69: $55-63$

Peterson, B. J. (1980). Aquatic primary productivity and the ${ }^{14} \mathrm{C}-\mathrm{CO}_{2}$ method. A history of the productivity problem. Ann. Rev. Ecol. Syst. 11: 359-385

Renger, E. H. (1983). PRPOOS Program in Hawaii, AugustSeptember, 1982. Data Report. IMR Ref. No. 83-5. Univ. of California, San Diego

Rigler, F. H. (1973). A dynamic view of the phosphorus cycle in lakes. In: Griffith, E., Breton, A., Spencer, J., Mitchell, 
O. (ed.) Environmental phosphorus handbook. Wiley, New York, p. 539-572

Sharp, J. H. (1974). Improved analysis for particulate organic carbon and nitrogen' from seawater Limnol. Oceanogr. 19: 984-989

Sharp, J. H., Perry, M. J., Renger, E. H., Eppley, R. W. (1980). Phytoplankton rate processes in the oligotrophic waters of the central North Pacific Ocean. J. Plankton Res. 2: 335-353

Smith, R. E. H. (1982). The estimation of phytoplankton production and excretion by carbon-14. Mar. Biol Lett. 3: 325-334

Smith, R. E. H., Platt, T. (1984). Carbon exchange and ${ }^{14} \mathrm{C}$ tracer methods in a nitrogen-limited diatom, Thalassiosira pseudonana. Mar Ecol. Prog. Ser. 16: 75-87

Smith, R. E. H., Geider, R. J., Platt, T (1984). Microplankton productivity in the oligotrophic ocean. Nature, Lond. 311 : $252-254$
Smith, R. E. H., Harrison, W. G., Harris, L. (1985). Phosphorus exchange in marine microplankton communities near Hawaii. Mar. Biol. 86: 75-84

Solorzano L. (1969). Determination of ammonia in natural waters by the phenolhypochlorite method. Limnol. Oceanogr. 14: 799-801

Solorzano, L., Sharp, J. H. (1980). Determination of total dissolved phosphorus and particulate phosphorus in natural waters. Limnol. Oceanogr. 25: 754-758

Strickland, J. D. H., Parsons, T R. (1972). A practical handbook of seawater analysis, 2nd ed. Bull. Fish. Res. Bd. Can. 167

Williams, P. J. LeB., Heinemann, K. R., Marra, J., Purdie, D. A. (1983). Comparison of ${ }^{14} \mathrm{CO}_{2}$ and $\mathrm{O}_{2}$ measurements of phytoplankton production in oligotrophic waters. Nature, Lond. 305: 49-50

This paper was presented by Dr. R. J. Conover; it was accepted for printing on September 17, 1985 